\title{
Centralization of Risk Management in Business Companies: A Case Study on the Role of Specialist Departments
}

\author{
Michael Schwandt \\ Doctoral School of Enterprise Theory and Practice \\ University of Miskolc \\ H-3515 Miskolc-Egyetemváros, Hungary \\ E-mail: Michael-schwandt@web.de
}

Received: March 27, 2015 Accepted: April 15, 2015 Published: May 8, 2015

doi:10.5296/csbm.v2i1.7567 URL: http://dx.doi.org/10.5296/csbm.v2i1.7567

\begin{abstract}
As part of his Ph.D. studies, the author researches risk management in project business and focuses on the construction industry. This paper deals with the intra-company organization of risk management. In particular, it examines advantages and disadvantages of centralization and decentralization of risk management. First, the paper deals with various aspects of risk management on theoretical level, ways of organizing risk management structures and relating decision criteria as well as the relevant tasks of specialist departments. Methodology of further research is based on a case study that explores details of centralization and decentralization in business practice. In the center of the case study is the company Bilfinger Berger Civil, a large, international construction company, which is an active player in the project business and has already carried out a variety of construction projects successfully. On the one hand, the company units and persons involved in Bilfinger's risk management are introduced; on the other hand the tasks of the Group's centralized departments are illuminated in detail. This includes the Corporate Legal, Internal Auditing, Corporate Treasury, Group Controlling and Project Controlling departments. The risk management of Bilfinger Berger Civil is finally assessed in form of a summary. As a main result the reader gains information about theories on structuring risk management within business companies and numerous impressions on the practical application in a real construction company.
\end{abstract}

Keywords: Risk, Risk management, Project management, Construction business 


\section{Introduction}

Crisis situations do not happen from one day to the next. There are signals that point to them and risks pose only the last phase of a long process. The question of why some companies fail to foresee their economic troubles is a legitimated one. Did they recognize the changes that took place in the company's environment but their decision-makers failed to see the significance? Or was the management not suited to properly handle the situation?

The design problem with regard to the organization of risk management essentially consists in integrating the elements of risk management into the overall structure of the company in the best possible way. Diederichs et al. (2004) argue that the objectives and tasks of the risk management organization form the basis of action, with the following points at the forefront:

- Establishment and maintenance of a uniform company-wide risk culture.

- Coordination of the risk management processes and supervision of the tools of risk controlling.

- Continuous provision of information to the management through a risk reporting.

- Advise and communication of methods for the fulfilment of tasks throughout the entire company.

- Design, improvement and adjustment of all components of the risk management system.

- Initialization of risk controlling measures.

\section{Literature Review}

Keitsch (2000) describes the function of risk management as a higher-ranking command, whose objective can be seen especially in the risk control, risk assessment and risk evaluation of the entire company. According to the author's view, the organizational establishment of risk management is therefore part of the responsibility of the executive management. The need for this arises from the fact that the business objectives and guidelines for the company and its different parts are both set up and under responsibility of the top management. Therefore, it also belongs to the duties of the management to create the organizational prerequisites for efficient risk management, to establish risk measurement and assessment procedures, to establish risk principles and provide guidelines, what measures to take if certain risk situations occur. Of course, it is possible to delegate some of these tasks to the specially created position of a chief risk officer. Priermeier (2005) notes, however, that the sovereignty of risk management always lies with the executive management. The management must be able to permanently or at least to a clearly defined cycle assess the actual risk situation of the company and to ensure that risk situations are controlled conform to the operational and strategic objectives of management. This is seconded by Füss (2005) who, even in the presence of an internal audit function, sees the function of risk management located at the level of top management.

In order to increase the effectiveness of the risk management system, it is necessary to anchor it in both the processes and in the organizational structure of the company. It is not enough to 
incorporate risk management into the functional structure, such as the installation of a responsible staff unit. The integration into the processes of the company must take place, too. Haller (1986) recommends to build the risk management organization on existing organizational structures and to take into account individual company requirements: 'There does not exist a single proper organization of risk management: Only the specific security needs, combined with the given and to adopt structures and processes lead to the optimal solution.' From this, he derives two fundamental questions concerning the actual organizational structure of risk management:

- Which of the already existing organizational structures are suitable or already in action for fulfilling special security needs?

- Which organizational gaps must be closed with regard to the security of the entire company?

Schuy (1989) recognizes that the organizational integration of risk management depends on the specific situation of the company and the environmental conditions. In case of a stable risk situation the creation of a central risk management office offers the most benefits. From here, a company-wide unified system can be developed and its compliance verified, further coordination and controlling tasks can be performed. Further, increased transparency and the opportunity to generate special expertise are counted among the advantages of a central risk management function. This contrasts with decentralized risk management units that can exploit their advantages especially in great complexity of the risk situation and high dynamics of environmental change. Small, decentralized units generally have not only more knowledge about the situation on site, but are often also able to act faster and more flexible. In large companies, it is of course possible to combine both forms of organization with each other.

Wolf/Runzheimer (2003) also dealt with the establishment of risk management within the organization and come to similar conclusions. They introduce three concepts that have proven their value in business practice: the separation principle, the principle of integration and the mixture of both embodiments. The separation principle is similar to centralization and contains the formation of a separate agency or department for risk management. It has the advantage that responsibilities are clearly defined and risk management enjoys a relatively high status within the company. The degree of structuring and systematization in the process flow is highest compared to the other systems, so a uniform risk management system is normally anchored across the enterprise. This is offset by the extra cost of a separate risk management department, which always has to prove its alleged increased benefit. Furthermore, the distance of a central risk management body from the place of origin of the risks is considered disadvantageous because stakeholders locally often have a higher knowledge, for example in relation to product-specific or country-specific needs. These disadvantages are counteracted by the second alternative, the principle of integration. The principle of integration provides to integrate risk management activities in the line organization and therefore renounces the installation of a separate department. This often allows improving the quality of the results of risk management, because responsibility is 
delegated to the know-how carriers of the respective functions. Compared with the principle of separation, through the integration principle cost savings can be achieved, since no additional jobs need to be created. However, this can also lead to overloading of management who perceive risk management and related disclosure as an additional burden. The danger occurs that it degenerates into daily business and goes lost. This threat can be countered by the simultaneous application of both the aforementioned strategies, leading to the formation of mixed forms of organizational establishment of risk management and forms the third alternative course of action. How the organizational integration is ultimately realized, depends to a large extent on the entity's specific circumstances, as a guideline the authors recommend the following decision criteria:

- Specific restrictions regarding the sector or the legal form (for example specifications for set up).

- Risk appetite of the management of the company: a risk shy organization usually chooses the rather safe separation principle.

- Risk awareness of the employees: a high degree of awareness and sensitivity of employees regarding risks and early detection second the implementation of the integration principle.

- Organizational structure: here no uniform recommendation is possible about a specific concept, but the complexity of structures and the degree of division of labour have to be taken into account.

- Quality of existing planning-, controlling- and checking instruments in the sense of risk management: the more the risk aspect is in focus already, the more the integration concept is suitable.

- Aspects of costs: usually integration concepts are cheaper in setting up.

Saitz (1999) deals with the fulfilment of risk management activities in different sub-areas of a company. He notes that the separation of functions and responsibilities in large enterprises is simpler than in medium-sized and small businesses. This makes it possible to assign the various sub-areas of risk management to different organizational units. Saitz describes the distribution of responsibilities according to Table 1:

Table 1. Task- and responsibility matrix by Saitz (1999, p. 86)

\begin{tabular}{lccc}
\hline \multicolumn{1}{c}{ Task } & $\begin{array}{c}\text { Specific risk } \\
\text { manager }\end{array}$ & Operative Units & Internal audit \\
\hline Specific methods and processes & $\bullet$ & & $\circ$ \\
Information / communication & $\bullet$ & $\bullet$ & \\
Identifying of risks & & $\bullet$ & \\
Assessment of risks & & $\bullet$ & $\circ$ \\
Measures & $\circ$ & $\bullet$ & \\
Process integrated checks & $\circ$ & & \\
\hline
\end{tabular}


Inter-process checks

Reporting per legal unit

Summarizing Risk report

Risk controlling

Supervision of the functionality of the

system independently from processes

Support of operative units

- Main competence o Support

Regarding the often-mentioned separate position of a risk manager Haller (1986) notes: 'For psychological reasons, however, it would be more appropriate to call the designated "Risk Manager" "Head of Security Coordination" (or "Coordination Risk Management"), in order to avoid from the beginning the impression that this personality is solely responsible for risk management.'

\section{The role of the specialist departments}

To the extent permitted by the size of the company, the different areas of the business company, such as the finance department, controlling, accounting and risk management, should operate as separate supervising units. Under this separation, especially the separation of powers and responsibilities is to understand, because the separation of functions is also a tool for risk reduction. The delineation of the different areas from each other should be well defined, unambiguous, non-overlapping, writing arrested and known to the employees of the departments concerned. Mutually incompatible activities, such as the completion of financial transactions and the accounting thereof, should always be performed by different persons. This includes in particular the clear separation of authorization, execution, accounting and supervision of operational processes. This is true even for companies in which the size of the company or the small number of transactions do not allow continuous separation of functions. Supportive for the separation acts in addition the spatial separation of the various departments from each other. The separation of functions can also be reinforced through regular job rotations, with personnel changes across functional areas.

A special role in the risk management system is assigned to the controlling what is justified by the particular task spectrum of the controlling department. On the one hand, it creates, collects and manages operational metrics, analyses them for example in the form of target-actual comparisons and evaluates the results. On the other hand, the activity of the controlling department is highly future-oriented, there are many tasks of corporate management and process optimization perceived, the planning process is coordinated and proposals for decisions are prepared. After having obtained information the controller is therefore also involved in the process of monitoring and controlling risks. This results in at least a partly responsibility for risk management.

In addition to the controlling department, the internal audit section of a company is of great importance in the perception of risk management tasks. In contrast to other departments, it is 
generally not integrated into the business process and therefore works as an independent staff department in order to meet versatile monitoring tasks, usually reporting directly to the Executive Board. Its sphere is comparable with that of the external auditor; however, in several areas it is of even bigger size. While the external auditor is often limited to the examination of the financial and accounting system, the task of internal auditors is according to Keitsch (2000) the 'audit of company activities, structures, functions and workflow processes in the form of a process and risk-based approach.' Condition for an effective, objective and neutral work of the audit department is the creation of the conditions necessary by the management, which consist according to the author of the following elements:

- Fundamental freedom of judgment

- Freely exercisable critique

- Absolute independence in the task, even from the management of the company.

Furthermore, the author mentions the following aspects that form the focus of the audit procedures carried out by the internal audit department:

- Regularity - compliance with laws and other legal regulations, as well as with internal policies, instructions and processes.

- Efficiency - Review of the economic effects of internal company processes and systems, based on target-actual comparisons with the goal of optimizing costs and increasing efficiency.

- Expediency - review of operational processes and organizational structures under the aspects of a meaningful, purposeful interaction.

- Riskiness - Identification of risk across the enterprise, from financial to operational level.

- Security - Ensuring the security of the entire company by making sure the operational processes, data security or the presence of contingency plans.

Similarly to the external auditor, it is also recommended for the internal audit department to summarize the results of the audit, along with recommendations for corrective actions, in the form of an audit report that is addressed to the Executive Board. This will not only satisfy the documentation requirements of monitoring processes, but is also helpful for pursuing the implementation of recommendations and solves as a starting point for future risk provisions. The real significance of the audit department and its recommendations, however, lies in its role as Internal Consulting or In-House advisor. It should not only be focused on errors and defects in the past, but in a forward faced approach risk factors should be pointed out and weaknesses should be identified under the above-mentioned aspects of regularity, efficiency, expediency, riskiness and security. The internal audit function in the ideal case, in addition to monitoring tasks also carries out advisory activities and becomes thus an indispensable element of the risk management process.

Due to the presence of a functioning internal audit department, the basis for a risk management system can be defined. On the one hand it meets all legal requirements and on 
the other hand contributes significantly to the early detection of risks and taking appropriate action. As a supervising unit, the internal audit is an integral part of the risk management system. However, this functional area is in many companies poorly or not at all present, reference being made to the small size of the company or trust in the work of the external auditor. As a result, other departments sometimes do the tasks of the internal audit or the management itself, sometimes they are not done at all, what in many cases is accompanied with a suboptimal risk provision and can also amount to a threat to the company.

\section{Bilfinger Berger Civil at a Glance}

Bilfinger Berger Civil comprises the Bilfinger Group's activities in the area of construction; the business is focused on demanding infrastructure projects. The company ranks among the recognized suppliers for large infrastructure projects and was able to work out an excellent reputation. The expertise of the company is concentrated in specialized units, whose competence the strong competitive position is based on. These include the core technologies bridge construction, tunneling, transportation infrastructures, civil engineering, hydraulic engineering and water technology.

The focus of the business is on international markets, selected European and African countries, the Gulf region as well as in Germany. Although being a German company, about $80 \%$ of the revenue is generated abroad. The business is affected by the strong dependence on public investment and the business cycle as a whole. Furthermore, clients often base their project awarding policy exclusively on the cheapest offer without rewarding quality sufficiently. Another characteristic is the relatively high radiation effect of individual risky projects on the earnings situation of the whole company. Regardless of this, the list of projects handled is very impressive, and includes the largest offshore wind park in the world off the coast of Denmark's with 91 wind turbines. In Doha, Qatar, the company built a completely new urban area for 20,000 inhabitants, consisting of the turnkey construction of about 6,000 apartments in total and a contract value of over 1 billion Euros. In Switzerland Bilfinger Berger Civil was involved in the construction of the Gotthard Base Tunnel, this occurs at a depth of $800 \mathrm{~m}$ and will be the longest railway tunnel in the world after its completion with a length of $57 \mathrm{~km}$. In 2008 Bilfinger Berger Civil generated a turnover of more than 4 billion Euros and had a workforce of more than 14,000 employees.

\section{Company Units and Persons Involved in Bilfinger's Risk Management}

In the risk management of Bilfinger Group, all business units are involved, that work along the line organization. In addition to the Supervisory Board and the Audit Committee formed therefrom, this includes the Board, the divisions and daughter companies, their branches and the executed projects and finally each employee. A special role is played by the central departments that operate in cooperation with all levels of the company hierarchy.

\section{Supervisory Board}

The task of the Supervisory Board is to advise the Board in the management of the company and to monitor its work. Benchmarks for the supervision are the legality, regularity, suitability and profitability of the group wide management by the Board. Another object of the 
Supervisory Board is to review the reports submitted by the Executive Board and to test the information provided on their plausibility as well as critically question it. The Supervisory Board is involved in decisions of fundamental importance to the company. Business transactions requiring its consent will be examined and discussed with the Supervisory Board. These include the acquisition and disposal of equity investments, the submission of bids for major projects and the investment budget.

Audit Committee

The Audit Committee is set up by the Supervisory Board and at Bilfinger consists of three members. In accordance with the German Corporate Governance Code the Audit Committee is concerned in particular with issues of accounting and risk management, the necessary independence of the external auditor, the assignment of the mandate to the auditor, the determination of auditing focal points and the fee agreement. In addition to the external auditors, the Audit Committee of the Supervisory Board is the second instance that reviews the risk management system of Bilfinger.

\section{Executive Board}

The Executive Board conducts the business of Bilfinger SE in accordance with the laws, the Articles of Association and the Rules of Procedure. In addition to the commitment to achieving sustainable growth in shareholder value and developing the strategic direction of the company the Board ensures appropriate risk management and risk control. The Board, supported by the central departments sets up central rules of conduct for dealing with risks within the Bilfinger group. Their documentation is ensured through manuals, instructions, circulars, rules of procedure or by reference to relevant laws. Orders of large scale or involving special risks can only be accepted if the Board expressly allowed it in individual cases. The distribution of tasks within the Executive Board is documented in the schedule of responsibilities, however, the final responsibility for the risk management system lies with the Chief Executive Officer.

\section{Divisions and Daughter Companies}

On the level of daughter companies and divisions, the bodies responsible for management (Board, Managing Directors) are in charge for an effective risk management system of each unit. They are therefore to be considered as responsible for risk management. The implementation of the necessary risk management measures and risk monitoring lies usually in the responsibility of the operating units and is therefore decentralized.

\section{Branch Offices and Projects}

On the level of branch offices, the management of the respective branch office, on the level of projects, the project management is responsible for an effective risk management system.

\section{Employees}

Across the Group, all employees are part of the risk management system. The individual employee is risk manager; therefore, the risk regulation also applies to all employees of the 
group. The management considers it as an ongoing task, at the various levels of management and all employees to further promote and sharpen risk awareness.

Group Headquarter

The central departments of Bilfinger SE - Engineering, Accounting, Finance, Legal, Human Resources, Tax, Project Controlling, Purchasing, IT Management and Communication - using their higher-level expertise take over support and control functions in the risk management system. They design processes, define policies and methods for risk management and report to the Executive Board. On the level of central departments, active risk control is therefore primarily operated by monitoring the operating units relating to the management of risks. In addition, the central experts take advisory roles in dealing with risks.

\section{The Functions of the Specialist Departments at Bilfinger}

The central departments within the Bilfinger Group play a specific role in relation to the risk management system. They form a link between the operative units and the Board of Directors. In consultation with the board, the central departments work as group-wide supervision units. They have a comprehensive right for information as well as individually defined guideline competencies and participation rights in relation to their peers in the operative companies. The company's headquarter is in addition responsible for super ordinated controlling functions. The central departments of Controlling, Treasury, Project Controlling, Internal Auditing and Legal report regularly and comprehensively from their respective specialist perspectives on possible risks to the Board. The group handles risks associated with large-scale projects through a clearly structured task sharing within the central departments:

- The Corporate Legal department reviews project risks resulting of contract law, and has the lead role in lawsuits.

- Internal Auditing reviews the effectiveness of all operations and procedures. In addition, audits at the level of operational units are carried out.

- Corporate Treasury supports the board significantly in its decisions on financing, internal lines of credit and bank guarantees.

- Group Controlling is responsible for the monthly reporting of all key performance indicators and active controlling of the subsidiaries.

- Group Project Controlling supports the projects from quotation to completion. The economic development of each project will be continually and critically analyzed irrespective of the responsible operating unit.

The central departments have a prominent position within the risk management system; therefore, their activities will be explained in detail.

\subsection{Corporate Legal}

Corporate Legal is a service and staff unit of the Company. In general, the operational units must inform the central department regularly about relevant facts. In addition, the Board has 
determined the supervision function of the department in relation to their peers in the operational companies in the form of policy competences or participation rights. In the case of policy-making power, the responsible persons in the operational area are required to comply with specific rules made by the central department, either generally or in specific cases. In the case of participation rights, each matter is being processed by the relevant expert in the operating unit in coordination with the central department. The specific tasks of the department include the following activities:

- Providing advice and support to the Executive Board, the corporate functions of the holding as well as all corporate units and associated companies in Germany and abroad,

- Management of legal risks in the course of bid preparation, contract closings and the processing of contracts,

- Quarterly reporting to the Executive Board on serious legal risks,

- The responsible management of legal disputes, including the evaluation of risks for treatment in corporate accounting,

- The selection, retention and supervision of external lawyers and

- The uniform application of the law in all areas of the company as well as the assistance in the Group-wide implementation of Executive Board decisions.

The Corporate Legal department is divided into the Corporate Law section and the Legal Services section. Their work focuses on the following areas:

Corporate Law

- Providing advice in the founding of new companies and in the acquisition or sale of subsidiaries.

- Review and conception of company articles and bylaws, handling of corporate formalities for all Group companies.

- Review and conception of property purchase and sale agreements of overriding importance.

\section{Legal Services}

- Review, conception and comprehensive risk analysis for complex agreements in all business units as well as participation in the negotiation of such agreements.

- Participation in the preparation of Executive Board submissions on the approval of projects and on initiating litigation.

- Project-related legal advice including the pursuit of payment claims and defence against unjustified demands.

- Advice and support in securing payment claims, especially in connection with project developers and the like or projects with significant advance performance obligations. 
- Legal support for the operating units in all questions of legal compliance regarding the deployment of subcontractors and suppliers.

- Pursuit of outstanding payments as well as assistance with sensitive contract situations such as termination or work stoppages.

- Review, conception and negotiation of PPP projects as relates to concessions, project financing, equity commitment, construction and operation.

- Arrangement and review of joint venture and consortium agreements.

- Drawing up business terms and conditions, especially for subcontractors and suppliers.

- Advice regarding the awarding of public-sector orders.

\subsection{The Internal Audit Department}

Internal Auditing supports the Executive Board in monitoring all corporate functions based on the processes documented in risk management. The internal regulations, approved by the Executive Board, are providing the framework for the work. It reports to the Chief Financial Officer, acts independently and reports directly to the Supervisory Board's Audit Committee in targeted issues. The primary task of Internal Auditing is to safeguard the company from asset losses in all organizational units and at all levels of the organization. Activities focus on:

- Examination of transactions with regard to risks and opportunities.

- Review of the accuracy and thoroughness of internal and external Finance and Accounting processes.

- Analysis of business models and economic development.

- Best practice sharing among the individual Bilfinger units.

- Examination of the internal control systems and development of suggestions for their improvement.

- Audits of the financial statements of subsidiaries and affiliated companies not audited by external auditors.

To execute these tasks Internal Audit carries out different audits. Generally, the audits are carried out in accordance with a risk-oriented audit approach. It is not the goal of the audit to cover the full range of possible auditable areas, but rather, through a systematic risk identification within the framework of the audit preparations, to find a selection of subjects tailored to the organizational unit. The resulting scope is made known to the unit to be audited in advance. However, Internal Auditing reserves the right to adjust the scope during the course of the audit. In detail the following audits are carried out:

- Corporate Audit

- Project Audit

- Compliance Audit 
- Fraud Scan

- Audits of annual financial statements

- Special Audits

Corporate Audit

A corporate audit is the most general type of audit, can be carried out in any unit of the group and its subsidiaries and affiliated companies. Typical units that can be subject to a corporate audit are branches and subsidiaries. A corporate audit usually focuses on the following issues: Business model and strategy, market and competition, functions and personnel, economic development, major projects, balance sheet items, net working capital and liquidity developments as well as processes and procedures. The recommendations made by Internal Auditing are summarized in the appendix of the audit report as a to-do list. Internal Auditing will check the status of their implementation in a follow-up.

Project Audit

In addition to the tasks described under corporate audit, the following themes are investigated in detail in the course of a project audit: Construction site control (cost controlling, reported volume, claim management and procurement), Commercial processing (monitoring of receivables, liquidity management and settlement of costs) and in case of joint ventures, specific themes such as the JV success report and partner accounts. As during a corporate audit, recommendations given by Internal Auditing will be summarized in a to-do list attached to the audit report. Internal Auditing will check the status of their implementation in a follow-up.

\section{Compliance Audit}

The compliance audit represents a comprehensive, systematic and documented evaluation of all relevant aspects of the internal control system (ICS). It can be part of a corporate or project audit or take place individually as special compliance audit. The audit process identifies existing gaps and uncertainties in the internal control system and formulates measures to remove any deficiencies found. Key areas for a compliance audit include, among others: Bank transactions, cash management, creditor and invoice analysis, debtors and payment reminder system, procurement, equipment, materials and warehouse, wages and salaries.

\section{Fraud Scan}

Twice a year, Internal Auditing carries out a fraud scan in selected corporate units. The primary goal of a Fraud Scan is the disclosure of fraudulent behavior using certain data analysis methods. In addition, these analyses aim at identifying current weaknesses in the systems or processes and at formulating measures to remove any deficiencies that are found. Internal Auditing uses analytical audit software to prepare the data sets during the audit. External consultants are supporting Internal Auditing as and when required. 
Audit of Annual Financial Statements

Internal Auditing is required by the Executive Board to carry out audits on the annual financial statements of the Group's subsidiaries and affiliated companies not audited by external auditors. The audits are carried out in a primarily risk-oriented manner in view of reliable results and analogous to the procedure of external auditors. The reporting is presented in an abbreviated and simplified form.

Special Audits

In the context of special audit tasks, the internal audit department deals with special issues raised by the Board or the business units. These may affect both areas of daily business and fundamental problems and strategic issues.

\subsection{Corporate Treasury}

Corporate Treasury secures the financial flexibility and resources necessary to sustainably achieve strategic corporate objectives. The department manages financing and liquidity risks on a Group-wide level and has the goal of generating a positive value added. The central controlling functions comprise, in particular, the areas of financial risk management, liquidity management, banking policy, loan and surety facilities as well as financial reporting. Corporate Treasury also acts as an in-house bank for Group companies. In addition, the department provides support to the operating units in the areas of project financing, transactions, guarantee processing and currency hedging. According to the variety of tasks, Corporate Treasury operates different sections. These include Corporate Financing / Risk Management, Cash Management / Risk Control and Guarantee Management.

\section{Corporate Financing / Risk Management}

Corporate Financing is involved in strategic financial planning as well as establishing and monitoring compliance with the funding policy of the Bilfinger Group. Group funding concepts are developed based on financial and capital market analyses and are later implemented in negotiations with banks and other external funding sources. Financing partners are informed about current business developments on an ongoing basis and are selected based on resulting possibilities of a partnership. Corporate Treasury also serves as point of contact for Group companies regarding financing questions. It arranges internal approvals and sets up or accompanies negotiations of cash/surety lines of credit, lease financing and financing of projects with external partners. The unit also handles Group-internal financial investments or borrowing outside of the Cash Pool.

In addition, Risk Management also advises Group units on a range of questions regarding financial risk management. These include, along with the hedging of economic, political or other payment risks in project work, primarily the hedging of risks from exchange rate or price changes in foreign currencies, raw materials or interest rates. Either such transactions are, without widening margins, mediated by the central department, or they are directly arranged between the department and a unit within the Group in order to achieve the best market prices by pooling resources. Ideally, opposing risks can be netted at Group level. In 
accordance with the guidelines of the risk committee, Risk Management is responsible for controlling the remaining financial risks at Group level as well as for the investment of pension funds.

\section{Cash Management / Risk Control}

This unit is responsible for risk control, which includes the recognition, evaluation, controlling and managing of financial risks (counterparty-, interest-, currency- and raw material-risks) as well as the enhancement of financial-guidelines. Risk Control is also responsible for controlling Group-internal derivatives and supports the operational units in the preparation of hedge accounting for interest rate and inflation derivatives. Activities include the development and administration of the Treasury's software (web reporting, the Guarantee Administration System, the Treasury Management System), as well as responsibility for optimizing interfaces and Treasury-relevant processes, too.

\section{Guarantee Management}

The central department is responsible for the Group's centralized guarantee management. The unit applies for sureties, guarantees at banks and credit insurers on behalf of Group companies, and is responsible for issuing guarantees within the Group. As part of their activities, Guarantee Management supports Group units in the negotiation and formation of surety and guarantee agreements and seeks out appropriate guarantors. The surety provision statement, as well as the management and monitoring of the surety portfolio of the internal (Group companies) and external (banks and credit insurers) guarantee facilities also belong to the responsibility of the unit.

\section{Cash Pooling}

In a Cash Pool, the balance of a participating account holder is automatically set to zero and transferred to the pool's master account at the end of each booking day. Instead of facing claims or liabilities in connection with a bank, participating companies will be liable to the parent company. The key goals of the project include improving interest income, reducing transaction costs, creating clear structures and simplifying procedures and, in particular, streamlining bank and account networks. Currently, the Cash Pool consists of more than 200 companies with more than 320 accounts.

\subsection{Corporate Controlling}

The Corporate Controlling department is responsible for the provision of crucial management information for the Executive Board of Directors. Among the main objectives and tasks are the regular, prompt and standardized reporting as well as the processing of the data provided by the operational units for business management purposes. By the permanent observation of the business development, Corporate Controlling compiles a consistent picture and an independent appreciation of the economic situation of the group companies and analyses opportunities and risks. Further essential tasks of the department are the definition of reporting standards as well as the continual advancement of the management reporting instruments according to the changing information requirements of the decision makers. In 
addition, the unit is responsible for the administration, adjustment and continual improvement of supportive reporting and information systems. The department has the unlimited right to information and access in the monitored units. Due to the variety of tasks, the central department consist of a Business Controlling unit, a Management Reporting unit and a Management Business Intelligence unit.

Business Controlling

The Business Controlling section is responsible for the regular analysis and comprehensive evaluation of the operative units. Tasks and responsibilities comprise of the following:

- Business reviews on all levels of the units that are monitored.

- Establishment of an independent assessment with respect to the economic development.

- Discussion of the findings with the management and report to the responsible member of the Executive Board of Directors.

- Indication of opportunities and risks as well as of undesirable developments or inconsistencies, proposing of counter measures.

- Preparing of 'Short Notes' on pressing respectively relevant own findings or on commissioned issues (special projects).

- With regard to the contents, preparation respectively follow-up of working sessions of the executive board of directors with the operative units.

- Opinion on applications for business that is subject to approval.

- Opinion on major investments by way of calculating the return on investment.

- Monitoring of the implementation of measures in its area of responsibility.

- The task of controlling is not limited to the request for information on the level of the sub-group but also requires business reviews on the level of subordinated units.

\section{Management Reporting}

The Group Reporting System takes into account four principal groups of subjects: Changes of volume and order situation (Volume and Contract Reporting), profitability (Profit and Loss Reporting), Changes of assets and liabilities (Cash Flow Reporting) as well as the Return on Capital Employed and optimization of working capital (Capital Employed Reporting). The tasks and objectives of the Management Reporting Unit include the following:

- Provision of a monthly, quarterly and yearly self-consistent group reporting which has the Bilfinger executive board of directors as its principal beneficiary.

- Definition of reporting guidelines.

- Advancement of the management reporting instruments.

- Consulting and support for the divisions with respect to economic and administrative 
questions of the reporting system.

- Preparation of special reports and ad-hoc analysis.

- Integration of companies directly acquired by Bilfinger into the existing reporting system.

Management Business Intelligence

The tasks and objectives of the Management Business Intelligence section include:

- Administration of the corporate systems CORE, COBI and FDWH.

- Creating IT-concepts to fulfil new reporting needs.

- Interface role for topics of controlling and IT.

- Contact for ad-hoc-analysis and Management Reporting.

- Consulting and supporting the divisions in questions around the corporate systems.

- Management of IT-projects and further development of the controlling IT-environment.

- Support and system sided backup of the monthly reporting.

\subsection{Project Controlling}

The central Project Controlling department monitors individual projects in the bidding phase, the negotiation phase, as well as in the execution phase and plays an essential role in the management of project risks. The monitoring process begins with the bidding phase of a project. The operational unit provides information about the project, possible risks and project characteristics in a standardized format. The information has to be submitted at the beginning of the offer preparing process by the respective operational management to the central department with all available information at this time. The central department checks the information and considers whether there is any criteria that justifies the refusal of approval to tender and agrees this with the management of the operational area and the responsible board member. If the evaluation of all criteria leads to an overall to negative impression, bid preparation and tender is called into question, but it is being tested in each case, what criteria are negotiable and whether the risks can be excluded in the offer. As part of its task, the Project Controlling department analyses and rates the bid preparation in terms of quality of bid processing, engineering, contracting, estimating, construction time, personnel and organization, as well as risks and opportunities. At the same time, the central department decides about the future intensity of monitoring the project at which the following options are possible:

- Due diligence of the entire project

- Observance of certain portions of the project

- Monitoring of the project during the entire bid preparation

- Attendance at the final calculation meeting 
- Consultation of other in-house departments

- Consultation of external special advisors.

In the analysis of the offer the preliminary bid amount, the risk review, pointing out of how and where the risks have been considered in the offer and personnel planning are the fields of special importance. If necessary, the central department sets up a supplementary report for the Executive Board. The responsibility for complete and accurate bid preparation and the implementation of the recommendations by the central Project Controlling always remains, however, at the relevant operating unit.

After submission of the offer by the operational unit, the central department monitors the project, where appropriate up to contract award. During this time, the operating entity is required to forward all information about the development of the project regularly and promptly to the corporate headquarter. Here contractual changes of any kind compared to the agreed terms of the offer are of particular importance, especially changes of contract terms, or increases or decreases of services and changes in the construction time or interim deadlines. Other focal points of observation are on the withdrawing of exclusions in the offer, discounts, the extension of the offer-binding period or bid bonds and of course changes in the risk profile of the project. Before signing of the contract, Project Controlling finally checks any negotiation results.

Projects that have been monitored by the central department during the offer phase are usually observed after placement of the order, too. However, so-called risk projects can newly be included in the monitoring process. These projects are already in the construction phase, however, have not been checked yet. The projects are characterized by abnormalities or signs of higher levels of risk, which the central department tries to counteract by more intensive care. The following criteria are used to define risk projects:

- With regard to the entire project: Difference between current profit forecast and the profit that is still needed to reach profit plans $>-5 \%$.

- With regard to the fiscal year: Difference between current profit forecast and original profit forecast $>-5 \%$.

If a project is monitored during the construction phase, the project management is required to make all requested contract documents or other documents available to the headquarter and to prepare regular monthly and quarterly reports. The central Project Controlling, for example, takes part in supervision meetings and regularly collects information about all relevant procedures and measures influencing the project, the progress of construction and other technical concerns. In addition, commercial details are checked, such as the result of the construction site at the reporting date or the result forecast for the end of construction time. In summary, the central department analyses and evaluates projects in the execution phase in terms of quality of construction management, engineering, contracting, performance and result, construction time, personnel and organization, as well as risks and opportunities. Furthermore, audits are performed, reports and analyses generated about risk factors and possible project control measures suggested. As in the offer phase responsibility for the 
proper execution and implementation of the recommendations remains in the relevant operating unit.

Parallel to the project monitoring the central department also reports to higher-level units. Reports will be provided to the project managers, as well as their line manager and the responsible Board member. Before finalizing and distributing the reports and analyses are sent to and discussed with the relevant project managers. In case of a different opinion the project management can represent their dissenting view in the reports.

\section{Conclusion}

Organizational integration of risk management depends on the specific situation of the company and the environmental conditions. In case of a stable risk situation the establishment of a central risk management office offers the most benefits. A company-wide unified system can be implemented; coordination and controlling tasks can be performed. Further, increased transparency and the opportunity to generate special expertise are advantages of a centralized risk management. This contrasts with decentralized risk management units that can exploit their advantages especially in great complexity of the risk situation and high dynamics of environmental change. Small, decentralized units generally have not only more knowledge about the situation on site, but are often also able to act faster and more flexible. In large companies, it is of course possible to combine both forms of organization.

The risk management system of Bilfinger Berger Civil was mainly driven by organizational measures. This includes primarily the creation of several specialized central departments. The legislative side explicitly requires the presence of an internal audit, but also other central departments, such as the Project Controlling, monitor the risk situation of the company and thus contribute to a legally compliant risk management structure. Risk management does not exist separately, but was integrated into the existing reporting structures and thus into the existing process structure of the company, whereby it is present at all levels of the Group.

A special position within the company comes to the central departments. In them, the expertise in the respective area is bundled to support and advise the operational units in their business. Important legal cases and contracts are handled by the Corporate Legal Department. The Treasury Department acts as the in-house bank for the entire group, while the Group Controlling collects the detailed reports of all business units. The Internal Audit Department and the Project Controlling accompany projects of outstanding importance or in individual cases if necessary. Many processes run together in the company's headquarter; the departments are at least given a voice in a variety of decisions. Furthermore, the central departments provide regular reports, such as quarterly or as separate risk reports, which support the Board in its work. On the other hand, the importance of corporate departments must not be overstated. On one hand, different thresholds are applied in reporting or in selecting projects to be observed. Therefore, not every project is accompanied through all phases of project life cycle and decision-making is delegated to intermediate management levels. On the other hand, the capacity and the number of employees in the corporate headquarter are limited, resulting in the necessity to focus on priority activities and apply broad guidelines. A centralized risk management does not exist. Neither is a central Risk 
Management Officer in charge, nor a risk management department installed as an independent unit. Rather, the principle of integration has been implemented, risk management is integrated in the organizational structure and the line functions of the company.

Additional potential for conflict is caused by the 'human element' in the project management, the fact that in all positions people with individual characters work, possessing subjective perceptions, vanities and other human weaknesses. The cooperation between the two endpoints of the Group hierarchy depends to a large extent on the personalities of the employees involved. Is it weakened by personal factors, asymmetry of information, delays and other conditions may arise that complicate the management of emerging risks. The 'human factor' comes also into play, when the employees are not aware that they themselves are the first and most important risk managers. In this respect, Bilfinger Berger Civil, however, is classified as a model, since in various media, the employees are named repeatedly as the most important risk managers.

\section{References}

Diederichs, M., Form, S., \& Reichmann, T. (2004). Standard zum Risikomanagement Arbeitskreis Risikomanagement. Controlling, 16, 189-198. http://dx.doi.org/10.15358/0935-0381-2004-4-5-189

Füss, R. (2005). Die Interne Revision - Bestandsaufnahme und Entwicklungsperspektiven (p. 53). Berlin: Erich Schmidt Verlag.

Haller, M. (1986). Risiko-Management - Eckpunkte eines integrierten Konzepts. Schriften zur Unternehmensführung, 7-43. http://dx.doi.org/10.1007/978-3-322-86198-6_1

Keitsch, D. (2000). Risikomanagement (p. 51). Schäffer-Poeschel Verlag Stuttgart.

Priermeier, T. (2005). Der Prozess der Risikosteuerung. Finanzrisikomanagement im Unternehmen (p. 91). Ein Praxishandbuch, Verlag Franz Vahlen GmbH, München.

Saitz, B. (1999). Risikomanagement als umfassende Aufgabe der Unternehmensleitung. Das Kontroll- und Transparenzgesetz, p. 86. http://dx.doi.org/10.1007/978-3-322-82782-1_3

Schuy, A. (1989). Risiko-Management - Eine theoretische Analyse zum Risiko und Risikowirkungsprozeß als Grundlage für ein Risikoorientiertes Management unter besonderer Berücksichtigung des Marketing. Europäische Hochschulschriften, Reihe 5: Volks- und Betriebswirtschaft, Band 1044, Frankfurt am Main, Bern, New York, Paris, p. 255

Wolf, K., \& Runzheimer, B. (2003). Risikomanagement und KonTraG - Konzeption und Implementierung (p. 156). Gabler Verlag. http://dx.doi.org/10.1007/978-3-322-94851-9

For the chapter about Bilfinger the following sources have been used:

Handbuch Bilfinger Berger Risikomanagementsystem, Zentralbereich Revision, Bilfinger Berger AG, Mannheim, 2007

Geschäftsbericht / Annual Report 2011, Bilfinger Berger SE, Mannheim, 2012 


\section{Macrothink}

Opportunity and Risk Report, Bilfinger SE, Mannheim, 2014

Intranet of Bilfinger SE (23.01.2015)

\section{Copyright Disclaimer}

Copyright for this article is retained by the author(s), with first publication rights granted to the journal.

This is an open-access article distributed under the terms and conditions of the Creative Commons Attribution license (http://creativecommons.org/licenses/by/3.0/). 